\title{
Municipal solid waste: the economic opportunity
}

\author{
S. Kathiravale, M. N. M. Yunus \& M. P. Abu \\ MINT Incineration and Renewable Centre (MIREC), \\ Malaysian Institute of Nuclear Technology (MINT), Bangi, \\ Kajang, Malaysia
}

\begin{abstract}
We currently live in a world where depletion of resources is beyond control. The call for sustainable development both environmentally and economically is spelt out loud and clear. Hence, the current and future generations must ensure that all resources shall be preserved, fully utilized and well managed. Generally, the developed countries generated more waste, recycle more and have the money to employ new technology to treat their waste. As for the developing and the third world countries, the waste generated is more organic in nature, which calls for lesser recycling, whereas disposal is by open dumping. The effects of this naturally would mean that in the lower income countries pollution to the water and air is huge as compare to the more developed countries. Action needs to be taken in a world where economic power determines the treatment method. Hence, the idea of recovering all 'wealth' in the waste is essential to ensure that even the poorest countries could benefit from all waste management technologies. For this to work, recycling, reuse and recovery of energy is essential in an integrated approach towards waste management. Many technology managers are working towards 'Zero Waste' these days but how far away is it?
\end{abstract}

Keywords: waste management, recycle, waste to wealth.

\section{Introduction}

Waste, regardless of its kind (either in solid or liquid form) is produced since the dawn of human existence and it is not excessive to say, waste is the first thing generated before people are able to contribute to the betterment of lives. 
Indifferent of the various definitions, the problems regarding the disposal and management of waste have then never been out of the issues of open discussion. This controversial subject has become more severe when the growth of waste has reach to its critical condition due to the increasing demands on the consumption of natural resources and raw material in the creation of products to enrich people's lives. Hence, the current and future generations must ensure that all resources shall be preserved, fully utilized and well managed.

Generation rates of Municipal Solid Waste (MSW) vary according to the economic and social standing of a country. This in return will also affect the management style of the MSW generated. Generally, the higher income community generated more waste, recycle more and have the money to employ new technology to treat their waste. As for the lower income communities, the waste generated is more organic in nature, which calls for lesser recycling, whereas disposal is by open dumping. The effects of this naturally would mean that in the lower income countries pollution to the water and air is huge as compare to the more developed countries. However on the other hand, does waste alone generate harmful gasses that pollute the world or does manufacturing, transportation and power production, which is rampant in the more industrialized countries contributing more towards pollution? This subject is argumentative and could be discussed at length. However, the environment cannot wait for its population to debate on the above matter. Action needs to be taken in a world where economic power determines the treatment method. Hence, the idea of recovering all 'wealth' in the waste is essential to ensure that even the poorest countries could benefit from all waste management technologies. For this to work, recycling, reuse and recovery of energy is essential in an integrated approach towards waste management.

\section{Waste generation rates}

Municipal Solid Waste (MSW) could be considered to be produced in proportion with the economic productivity and the consumption rate of the population of the countries resources. Countries with higher incomes produce more waste per capita and per employee, and their waste generally contains more packaging material and recyclable items. In low-income countries, the commercial and industrial activity is limited; thus recycling activities are limited. Table 1 reflects the generation rates as compared to the economic level and the management cost. In most low income countries, land availability, due to lack of economic value, makes it easier to operate open dumps as compares to developed countries where land cost is too high due to economic and residential demands which calls for more sophisticated management methods such as incineration, refuse derived fuel, composting, material recovery facilities and others [1,2]. At the same time, the generation rate with the related disposal cost alone does not reflect the MSW management condition in most countries. Many other factors, such as land availability, public opinion, political, economical and legal conditions too do govern over the decision made to tackle the MSW management problem in a country. 
Table 1: Global perspective of municipal solid waste generation rates and the respective management costs $[3,4]$.

\begin{tabular}{|c|c|c|c|c|}
\hline & Units & $\begin{array}{c}\text { Low } \\
\text { Income }\end{array}$ & $\begin{array}{l}\text { Middle } \\
\text { Income }\end{array}$ & $\begin{array}{c}\text { High } \\
\text { Income }\end{array}$ \\
\hline $\begin{array}{l}\text { Mixed Urban Waste - } \\
\text { Large City }\end{array}$ & $\mathrm{kg} / \mathrm{cap} /$ day & $\begin{array}{l}0.50 \text { to } \\
0.75\end{array}$ & $\begin{array}{c}0.55 \text { to } \\
1.10\end{array}$ & $\begin{array}{c}0.75 \text { to } \\
2.20\end{array}$ \\
\hline $\begin{array}{l}\text { Mixed Urban Waste - } \\
\text { Medium City }\end{array}$ & $\mathrm{kg} / \mathrm{cap} /$ day & $\begin{array}{l}0.35 \text { to } \\
0.65\end{array}$ & $\begin{array}{l}0.45 \text { to } \\
0.75\end{array}$ & $\begin{array}{l}0.65 \text { to } \\
1.50\end{array}$ \\
\hline Residential Waste Only & $\mathrm{kg} / \mathrm{cap} /$ day & $\begin{array}{l}0.25 \text { to } \\
0.45\end{array}$ & $\begin{array}{l}0.35 \text { to } \\
0.65\end{array}$ & $\begin{array}{l}0.55 \text { to } \\
1.00\end{array}$ \\
\hline $\begin{array}{l}\text { Average Income from } \\
\text { GNP }\end{array}$ & USD/cap/yr & 370 & 2,400 & 22,000 \\
\hline Collection Cost & USD/ton & 10 to 30 & 30 to 70 & 70 to 120 \\
\hline Transfer Cost & USD/ton & 3 to 8 & 5 to 15 & 15 to 20 \\
\hline Open Dumping Cost & USD/ton & 0.5 to 2 & 1 to 3 & 5 to 10 \\
\hline Sanitary Landfill Cost & USD/ton & 3 to 10 & 8 to 15 & 20 to 50 \\
\hline $\begin{array}{l}\text { Tidal Land } \\
\text { Reclamation Cost }\end{array}$ & USD/ton & 3 to 15 & 10 to 40 & 30 to 100 \\
\hline Composting Cost & USD/ton & 5 to 20 & 10 to 40 & 20 to 60 \\
\hline Incineration Cost & USD/ton & 40 to 60 & 30 to 80 & 70 to 100 \\
\hline $\begin{array}{l}\text { Total cost without } \\
\text { Transfer }\end{array}$ & USD/ton & 13 to 40 & 38 to 85 & 90 to 170 \\
\hline Total cost with Transfer & USD/ton & 17 to 48 & 43 to 100 & $\begin{array}{l}105 \text { to } \\
190\end{array}$ \\
\hline Cost as $\%$ of Income & $\%$ & 0.7 to 2.6 & 0.5 to 1.3 & 0.2 to 0.5 \\
\hline
\end{tabular}

* Income based on 1992 Gross National product data form the World Development Report, 1994.

As for Malaysia, the capital city of Kuala Lumpur is usually the center of attention for waste management problems due to the congestion and over production of MSW. It is reported that on average, the daily collection is about 18,000 to 25,000 tons/day for Malaysia and in Kuala Lumpur it is as high as 3,000 tons/day [6,7]. On average, the generation rate is about 0.8 to $1.2 \mathrm{~kg} / \mathrm{capita} / \mathrm{day}$ and this generation rate is increasing annually at a rate of 2 to $3 \%$. As for other Asian countries the generation rate increase is about 3 to $7 \%$. Table 2 shows some figures on the generation rates and the composition of the different classes of income based on a study done in Selangor.

As for Malaysia, the capital city of Kuala Lumpur is usually the center of attention for waste management problems due to the congestion and over production of MSW. It is reported that on average, the daily collection is about 18,000 to 25,000 tons/day for Malaysia and in Kuala Lumpur it is as high as 3,000 tons/day [6,7]. On average, the generation rate is about 0.8 to $1.2 \mathrm{~kg} / \mathrm{capita} /$ day and this generation rate is increasing annually at a rate of 2 to $3 \%$. 
Table 2: Generation rates and major waste components in the state of Selangor, Malaysia [4,5].

\begin{tabular}{|l|c|c|c|c|}
\hline & & $\begin{array}{c}\text { High } \\
\text { Income } \\
(>\mathrm{RM} \\
3,000)\end{array}$ & $\begin{array}{c}\text { Middle } \\
\text { Income } \\
(\mathrm{RM} 1,500 \\
\text { to 2,999) }\end{array}$ & $\begin{array}{c}\text { Low } \\
\text { Income } \\
(<\mathrm{RM} \\
1,500)\end{array}$ \\
\hline Generation Rate & $\mathrm{kg} / \mathrm{c}$ capita/day & 1.70 & 0.71 & 0.80 \\
\hline \multicolumn{5}{|c|}{ Composition } \\
\hline Food & $\%$ & 38.81 & 47.21 & 49.38 \\
\hline Paper & $\%$ & 12.81 & 12.28 & 12.58 \\
\hline Textile & $\%$ & 2.18 & 2.38 & 2.26 \\
\hline Rubber / Leather & $\%$ & 2.17 & 0.69 & 0.73 \\
\hline Wood & $\%$ & 1.16 & 0.82 & 0.45 \\
\hline Garden Waste & $\%$ & 11.26 & 8.64 & 5.94 \\
\hline Other Organic & $\%$ & 0.59 & 0.18 & 0.27 \\
\hline $\begin{array}{l}\text { Other (plastic, } \\
\text { metal, etc.) }\end{array}$ & $\%$ & 31.02 & 27.80 & 28.39 \\
\hline
\end{tabular}

\section{Waste management trends}

Too many residents of the world, generation of waste is considered a part of life which cannot be changed, but to some, the generation of waste is something that will eventually affect them if not managed properly. Having all the best waste management options available is good but a reflection of the current generation rates and the disposal methods is necessary in order to avoid overspending. This brings in the concept of BATNEEC (Best Available Technology, Not Entailing Excessive Cost) where the technology is suited to the problem and the situation in the country. However, there are some countries or rather counties/ states that do not process their waste in their own state, bring about the NIMBY (Not In My Back Yard) syndrome, which will entail excessive cost in just transporting the waste across the boarder [8]. Table 3 shows the amount of waste that is collected and how it is managed in a few countries. From the table it is good to note that most of the nations in the world are providing for the collection of waste to at lease $80 \%$ of that which is generated.

As for Malaysia, until the year 2000, land filling of the waste generated has been the main option. However, the 144 landfills and open dumps scattered all over the country is at a critical level of either at the end or beyond its lifespan. At the same time, Malaysia enjoys a high development rate and combined with the strict environmental regulations enforced, land for dumping of waste is scarce. Over the last 5 years, the management trends in major towns have changed from land filling to putting great pressure to recycle, recover and reuse. Kuala Lumpur has closed two landfills and created only one landfill, one transfer station and a Refuse Derived Fuel plant and Incineration plant is in the pipeline. The same could be said about Penang and Johor Bahru. However, the management style in the lesser-populated states is still landfill dependent. As for 
the central government, efforts are in the pipeline for the tabling of a national waste bill that will empower the local authorities to provide better management and allow for privatization of the collection and disposal of the MSW. A master plan for the nation on it wastes management policies and strategies has been prepared and earmarked for implementation until 2020 [8].

Table 3: Amount of waste collected and the management methods [9-18].

\begin{tabular}{|c|c|c|c|c|c|c|c|}
\hline Country & $\begin{array}{c}\text { Data latest } \\
\text { year } \\
\text { available }\end{array}$ & $\begin{array}{c}\text { MSW } \\
\text { collected } \\
(1000 \text { tonnes })\end{array}$ & $\begin{array}{l}\text { Population } \\
\text { served } \\
(\%)\end{array}$ & $\begin{array}{c}\text { MSW } \\
\text { collected } \\
\text { per } \\
\text { capita } \\
\text { served } \\
(\mathrm{kg}) \\
\end{array}$ & $\begin{array}{c}\text { MSW } \\
\text { landfilled } \\
(\%)\end{array}$ & $\begin{array}{c}\text { MSW } \\
\text { incinerated } \\
(\%)\end{array}$ & $\begin{array}{c}\text { MSW } \\
\text { recycled/ } \\
\text { composted } \\
(\mathrm{kg})\end{array}$ \\
\hline \begin{tabular}{|l} 
United \\
States
\end{tabular} & 2001 & 207957 & 100.0 & 722 & 55.7 & 14.7 & 29.7 \\
\hline Australia & 1999 & 13200 & & $\ldots$ & 95.0 & 0.0 & 7.3 \\
\hline Japan & 2000 & 52362 & 100.0 & 412 & 5.9 & 77.0 & 15.0 \\
\hline France & 2001 & $32 \quad 174$ & 100.0 & 540 & 43.2 & 32.2 & 24.6 \\
\hline Italy & 2002 & 29788 & 100.0 & 525 & 63.8 & 8.9 & $\cdots$ \\
\hline Spain & 2001 & 26340 & $\ldots$ & 595 & 59.6 & 5.6 & 21.6 \\
\hline Mexico & 2002 & 32174 & 86.0 & 367 & 97.6 & 0.0 & 2.4 \\
\hline Peru & 2001 & 1444 & 100.0 & $\ldots$ & 64.6 & $\ldots$ & $\ldots$ \\
\hline Madagascar & 2002 & 151 & 100.0 & ... & 100.0 & 0.0 & 0.0 \\
\hline Mauritius & 2003 & 351 & 95.0 & 303 & 100.0 & $\ldots$ & $\cdots$ \\
\hline Hong Kong & 2002 & 5399 & 100.0 & 773 & 63.7 & $\ldots$ & 36.3 \\
\hline Singapore & 2002 & 4402 & $\ldots$ & $\cdots$ & 3.7 & 55.0 & 41.3 \\
\hline Thailand & 2000 & 13972 & $\ldots$ & $\ldots$ & $\ldots$ & 0.8 & 14.3 \\
\hline
\end{tabular}

\section{The problem}

Waste generation at all points needs to be managed in a proper manner. The effects of this waste either managed or un-managed mostly could lead to either the pollution to water or air. In most cases water pollution is contributed by the improper management of landfills or just open dumps, which allows untreated or semi-treated leachate to flow into waterways causing tremendous health problems.

The standards and norms for handling MSW in industrialized countries have reduced health and environmental impacts substantially. About four decades ago, high-income countries required for open dumps to be covered daily with soil to curtail vector access, turning these dumps into controlled landfills. However, in the 1970s, when it became apparent that even controlled landfills could cause major water pollution, sanitary landfills become a necessity. This technology development allowed for the proper treatment of leachate and also for the collection of the landfill gasses [6].

In the case of Japan, it is estimated that as a result of MSW management, $38 \%$ of the amount of $\mathrm{CO}_{2}$ produced could come from incineration, while landfill generates $3 \%$, collection and transportation $4 \%$, crushing activities $4 \%$ and lastly the handling of plastics generates $51 \%$ of the total $\mathrm{CO}_{2}$ generated from waste management. In another study done in Japan, the amount of green house gasses generated from various waste management methods are shown on 
Table 4. As for Malaysia, the actual amount of gasses generated from the waste management of MSW is unknown. However data from the World Bank indicate the amount of $\mathrm{CO}_{2}$ emitted in Malaysia in 2000 were 123.6 million Metric tons and 2.44 million metric tons of $\mathrm{CH}_{4}$. This is emissions from all types of fuels.

Table 4: Amount of green house gases from waste management in 2000 Japan.

\begin{tabular}{|c|c|c|c|c|}
\hline \multicolumn{3}{|c|}{ Source } & GHG & $\mathrm{Gg} \mathrm{CO}_{2} \mathrm{eq}$ \\
\hline \multirow{3}{*}{$\begin{array}{l}\text { Emissions } \\
\text { from } \\
\text { Landfill } \\
\end{array}$} & \multirow{3}{*}{$\begin{array}{l}\text { Controlled } \\
\text { Landfill }\end{array}$} & Kitchen Garbage & $\mathrm{CH}_{4}$ & $1,205.5$ \\
\hline & & Paper / Fiber & $\mathrm{CH}_{4}$ & $2,576.4$ \\
\hline & & Wood & $\mathrm{CH}_{4}$ & $1,537.7$ \\
\hline \multirow{7}{*}{$\begin{array}{c}\text { Emissions } \\
\text { from Waste } \\
\text { Water } \\
\text { Treatment }\end{array}$} & \multicolumn{2}{|c|}{ Industrial Waste Water } & $\mathrm{CH}_{4}$ & 308.5 \\
\hline & \multirow{6}{*}{$\begin{array}{c}\text { Municipal / } \\
\text { Commercial } \\
\text { Waste } \\
\text { Water }\end{array}$} & \multirow{2}{*}{$\begin{array}{c}\text { Final Treatment } \\
\text { Plant }\end{array}$} & $\mathrm{CH}_{4}$ & 231.3 \\
\hline & & & $\mathrm{N}_{2} \mathrm{O}$ & 620.9 \\
\hline & & \multirow{2}{*}{$\begin{array}{c}\text { Domestic } \\
\text { Treatment Plant }\end{array}$} & $\mathrm{CH}_{4}$ & 418.9 \\
\hline & & & $\mathrm{N}_{2} \mathrm{O}$ & 360.7 \\
\hline & & \multirow{2}{*}{$\begin{array}{l}\text { Human Waste } \\
\text { Treatment Plant }\end{array}$} & $\mathrm{CH}_{4}$ & 34.0 \\
\hline & & & $\mathrm{N}_{2} \mathrm{O}$ & 868.6 \\
\hline \multirow{6}{*}{$\begin{array}{l}\text { Emissions } \\
\text { from } \\
\text { Incineration }\end{array}$} & \multirow{3}{*}{\multicolumn{2}{|c|}{ Municipal Solid Waste }} & $\mathrm{CO}_{2}$ & $12,804.5$ \\
\hline & & & $\mathrm{CH}_{4}$ & 11.2 \\
\hline & & & $\mathrm{N}_{2} \mathrm{O}$ & 650.1 \\
\hline & \multirow{3}{*}{\multicolumn{2}{|c|}{ Industrial Solid Waste }} & $\mathrm{CO}_{2}$ & $11,440.2$ \\
\hline & & & $\mathrm{CH}_{4}$ & 0.8 \\
\hline & & & $\mathrm{N}_{2} \mathrm{O}$ & $1,621.1$ \\
\hline & & Total & & $34,690.5$ \\
\hline
\end{tabular}

Generally, it is evident that no matter what the management method maybe, the effect on the environment is still unavoidable. The only way to reduce waste is to increase recycling and ultimately to stop the production of waste. This has to come into effect in terms of reducing the demand on goods and also ensuring the production of goods are full prove with $110 \%$ efficiency. This is something for the future but for the current market, waste management has to strike a balance between the environment and the economical returns. Most waste management methods other then the conventional landfill, demand high capital and operational cost. In the past, the government due to these projects being not bankable funds the waste management projects. Fortunately, technology has progresses and new laws allow for the trading of $\mathrm{CO}_{2}$ in open market which makes waste management viable and economically encouraging.

\section{The opportunity}

From the previous arguments, it is evident that the concept of recycle, reuse and recover is essential in minimizing the amount of environmental and economical 
damage that could be done if the waste is disposed off indiscriminately. However, management of waste requires considerable funds and many countries do not have the economic resources for high technology management. On the other hand private companies are looking at the government for capital expenditure to reduce the financial burden on the company. Hence, the financial model becomes an important tool in making the final decision on the management method.

At this point, the concept of waste to wealth becomes apparent. The need to recover maximum profits from the management method employed while ensuring environmental sustainability is the main objective. It is obvious that at every level of processing, there is money to be made if processed in a proper manner. Current technologies allow for even the inert ash material form the incinerators to be recycled into road payment or for the manufacturing of tiles. This would not only safe resources but allow for the extension of landfill lifespan while ensuring almost zero waste to the landfill.

Table 5: Conversation of MSW to RDF and the amount of recyclables obtained with improvement in calorific value (CV) [1].

\begin{tabular}{|l|c|c|c|c|c|c|}
\hline Food & $\begin{array}{c}\text { MSW } \\
\text { weight }\end{array}$ & $\begin{array}{c}\text { Removal } \\
\%\end{array}$ & $\begin{array}{c}\text { RDF } \\
\text { weight }\end{array}$ & $\begin{array}{c}\text { RDF } \\
(\%)\end{array}$ & $\begin{array}{c}\text { CV MSW } \\
(\mathrm{kJ} / \mathrm{kg})\end{array}$ & $\begin{array}{c}\text { CV RDF } \\
(\mathrm{kJ} / \mathrm{kg})\end{array}$ \\
\hline Plastic & 12.65 & 10.00 & 11.38 & 18.97 & $35,028.95$ & $6,646.57$ \\
\hline Paper & 7.99 & 10.00 & 7.19 & 11.98 & $14,528.85$ & $1,741.23$ \\
\hline Rubber & 0.65 & 10.00 & 0.59 & 0.98 & $21,310.43$ & 207.92 \\
\hline Yard & 7.92 & 10.00 & 7.13 & 11.88 & $13,653.13$ & $1,622.36$ \\
\hline Textile & 1.36 & 10.00 & 1.22 & 2.04 & $17,735.08$ & 361.57 \\
\hline Wood & 2.32 & 10.00 & 2.09 & 3.48 & $15,727.25$ & 547.36 \\
\hline Glass & 1.56 & 90.00 & 0.16 & 0.26 & & \\
\hline $\begin{array}{l}\text { Alum- } \\
\text { inum }\end{array}$ & 0.39 & 90.00 & 0.04 & 0.06 & & \\
\hline Ferrous & 2.01 & 90.00 & 0.20 & 0.33 & & \\
\hline Fine & 3.97 & 90.00 & 0.40 & 0.66 & $10,723.86$ & 70.97 \\
\hline Total & 100.00 & & 59.98 & 100.00 & $17,532.96$ & $19,277.00$ \\
\hline
\end{tabular}

* Note - all calculations based on dry weight.

In Malaysia, as mentioned earlier, the major cities have changed from total land filling to recycling, recovery of energy through incineration or even conversion of MSW to Refuse Derived Fuel (RDF). Table 5 \& 6 shows the removal efficiency of the RDF process and the expenses and probable income from managing the waste in an integrated fashion. These are projection figures for a commercial RDF plant, which will commence operation in 2006 for the area of Kajang, Selangor. This is just one option and there are many more methods on integrating the management methods to obtain fruitful income. 
Malaysia is also rich in bio resources and agricultural activity, which generate a lot of waste. These wastes could act as enhancing material to better manage the MSW generated while ensuring not much methane is emitted into the atmosphere. This will not only improve the quality of live in Malaysia but also ensure management of all waste material is handled properly while bringing economical returns to the investors.

The ideal about RDF production is that the plant allows for material recovery, which is an income to the plant, and then the organics are shred and either converted to RDF or fed into composters to generate biogases which instead are fed to a fuel cell to create Hydrogen fuel. The opportunities are unlimited, with the integrating of various technologies and various wastes to generate the most amount of income. However, the technology has to be developed locally where the 'knowhow' will be gained at the same time. Only by this method will Malaysia become an exporter of technology instead of just materials and products.

Table 6: Typical expense and income from managing MSW generated Kuala Lumpur [1].

\begin{tabular}{|c|c|c|}
\hline \multicolumn{3}{|c|}{ Estimated Expenses (RM/ton MSW) } \\
\hline Collection & 90 & \\
\hline Transfer Station & 32 & \\
\hline Landfill & 27 & \\
\hline Incineration & 100 & \\
\hline Refuse Derived Fuel & 30 & \\
\hline Composting & 33 & \\
\hline \multicolumn{3}{|c|}{ Possible Income (RM/ton MSW) } \\
\hline \multicolumn{3}{|l|}{ Recycling } \\
\hline Plastic & 20 & $\begin{array}{l}20 \% / \text { ton MSW - with } 20 \% \text { recycled - RM } 0.50 \\
\mathrm{~kg}\end{array}$ \\
\hline Metal & 18 & $\begin{array}{l}8 \% / \text { ton MSW - with } 75 \% \text { recycled }-\mathrm{RM} 0.50 \\
\mathrm{~kg}\end{array}$ \\
\hline Others & 5 & Estimated \\
\hline Energy from RDF & 29.5 & $30 \% /$ ton MSW $-3,500 \mathrm{kcal} / \mathrm{kg}-\mathrm{RM} 0.17 / \mathrm{kW} . \mathrm{h}$ \\
\hline Composting & 30 & $60 \% /$ ton MSW - 5\% compost - RM $1.00 / \mathrm{kg}$ \\
\hline Carbon Trading & 35 & 1.9 tons $\mathrm{CO}_{2} /$ ton $\mathrm{MSW}-\mathrm{USD} 5 /$ ton $\mathrm{CO}_{2}$ \\
\hline
\end{tabular}

Apart from just waste treatment, landfill mining and recovery of material from closed landfills are an option to be looked at. Most countries evolve from open dumps that receive all kinds of waste to sanitary landfills, which receive waste that has been recycled, thermally treated, and the inert only end up in landfills. By locating a material recovery facility or a RDF plant on a closed landfill or open dump, the plant could operate to recover some of the material that have been buried as fuel. On the other hand open dumps that have been closed could also be harvested for the landfill gasses that are emitted to be converted into electricity. This not only saves the environment but also 
generates electricity. Over a period of time, these landfills could also be converted into orchards, golf courses or even residential areas in years to come. The financial model for this is enormous and waiting to be taken.

\section{Conclusion}

Waste generated and managed in a proper manner is essentially good for the environment. However, with the advancement of technology and in the pursuit for a modern and more comfortable lifestyle, many of the countries are endangering the environment to the point of no return. It has already been established that in some countries, the background level of dioxin in the air is higher then the allowable cancer risk set as 1 pica gram $/ \mathrm{Nm}^{3}$. The way forward should be not treating the waste produced but on how not to produce waste in the first place. This would take a long time to achieve but some action needs to be taken in order to stop excess manufacturing in the name and glory of seeking a comfortable lifestyle, while at the same time the same people are advocating that the world cannot take the burden that the population is inflicting on to it.

\section{References}

[1] Sivapalan Kathiravale, 'PhD Thesis in Preparation', UKM, 2003.

[2] Manser, A.G.R., and Keeling, A.A., 'Processing and Recycling Municipal Waste', CRC Press, Inc., Boca Raton, Florida, 1996.

[3] Cointreau, Sandra, 'Occupational And Environmental Health Issues of Solid Waste Management: Special Emphasis on Middle and LowerIncome Countries', Report to the Waste Management Unit of the World Health Organization, Regional Office in Europe

[4] Ali Khan. M.Z. and Burney. F.A., 'Forecasting Solid Waste Composition - An Important Consideration in Resource Recovery and Recycling', Resources, Conversation and Recycling, Elsevier, 3 (1989), 1-17

[5] 'Municipal Waste Arising', www.un.org/depts/unsd/enviro

[6] Mohd Nasir Hassan, Sivapalan Kathiravale, et al. 2002, 'Municipal Solid Waste Characterisation Study of Kuala Lumpur, Malaysia’ International Solid Waste Association World Environment Congress \& Exhibition 2002, Istanbul Convention \& Exhibition Center, Turkey, July 8-12. 2002

[7] Sivapalan Kathiravale, et al. 2002, 'A Material Balance of the Municipal Solid Waste Generated by the Various Sources in Kuala Lumpu' World Engineering Congress 2002, Kuching Sarawak, July 22-25. 2002

[8] Muhd Noor Muhd Yunus, 'Developing Strategies for MSW Management $R \& D$ in Malaysia and the Repositioning of the Thermal Treatment Discipline', $3^{\text {rd }}$ I-CIPEC, Hongzhou, Chaina, October, 2004

[9] Earth Trends Data Tables: Climate and Atmosphere, 2005, World Resources Institute, International Energy Agency, United Nations Framework

[10] Earth Trends Data Tables: Energy Consumption by Source, 2005, World Resources Institute, International Energy Agency, United Nations Framework 
[11] Earth Trends Data Tables: Energy Production by Source, 2005, World Resources Institute, International Energy Agency, United Nations Framework

[12] Earth Trends Data Tables: Greenhouse Gas Emissions by Source, 2005, World Resources Institute, International Energy Agency, United Nations Framework

[13] Earth Trends Data Tables: Energy, 2005, World Resources Institute, International Energy Agency, United Nations Framework

[14] 'Municipal Solid Waste and its Role in Sustainability' A position paper prepared by IEA Bioenergy, www.ieabioenergy.com

[15] Sivapalan Kathiravale, Muhd Noor Muhd Yunus 2003, 'Recoverable Energy From Malaysian Municipal Solid Waste’ Bulletin Ingenieur, Malaysia, Vol. 21 Quarter 4/4 Dec 2003 Pg 8 - 12

[16] Blueprint on Waste to Wealth, Malaysian Institute for Nuclear Technology, in Print

[17] Earth Trends Data Tables: Green Gas Emissions from Fossil Fuel Burning by Sector, 2005, World Resources Institute, International Energy Agency, United Nations Framework

[18] Earth Trends Data Tables: Energy Consumption by Sector, 2005, World Resources Institute, International Energy Agency, United Nations Framework

[19] Earth Trends Data Tables: Resources Consumption, 2005, World Resources Institute, International Energy Agency, United Nations Framework 